\title{
The Effects of Work Force Diversity on Employee Performance in Singapore Organisations
}

\author{
Darwin Joseph R. ${ }^{1} \&$ Palanisamy Chinnathambi Selvaraj ${ }^{2}$ \\ ${ }^{1}$ AQ Lecturer cum Local Program Director (MIB-GGSB), MDIS Business School, Management Development \\ Institute of Singapore, Singapore \\ ${ }^{2}$ Researcher (Chemical Industry), Singapore \\ Correspondence: Darwin Joseph R., AQ Lecturer cum Local Program Director (MIB-GGSB), MDIS Business \\ School, Management Development Institute of Singapore, Singapore. E-mail: ramdar3@yahoo.com
}

Received: January 30, 2015

doi:10.5430/ijba.v6n2p17
Accepted: February 16, 2015

Online Published: February 19, 2015

URL: http://dx.doi.org/10.5430/ijba.v6n2p17

\begin{abstract}
Workforce diversity has been identified as one of the strategic capabilities that will add value to the organizations over their competition. As Singapore is one of the most globally competitive countries, it attracts highly skilled and extremely innovative people to work here. Age, gender and ethnicity are the most commonly diversified demographic variables observed among the workforce of many organizations. Thus, the present study focuses on the effect of the workforce diversity in terms of age, gender and ethnicity. If the diversity of the workforce is properly managed, it will provide positive benefits. If not properly managed, however, it could lead to negative results. A self-administered questionnaire was used to collect the views of employees in both the manufacturing as well as the service industries in Singapore. The reliability of the survey was tested by estimating Cronbach's alpha. The empirical relationship of age, gender and ethnicity of the employees with the performance was computed using Software Package for Social Science (SPSS). The analysis reveals that the three variables do not have a statistically significant impact on the performance of employees. Human resource programmes suggested by the employees to improve the effectiveness of workforce diversity has been recommended.
\end{abstract}

Keywords: age diversity, employee perception, ethnic diversity, gender diversity, workforce diversity

\section{Introduction}

Globalization and the Internet have reduced the gap in the time to market scale between large MNCs (Multi-National Corporations) and small SMEs (Small and Medium Enterprises). Thus, hyper competition is almost unavoidable in every field. Meanwhile, the technical challenge of industrial problems is getting more difficult as well as more complex. Customers in today's business world are considering the speed of delivery of solutions as one of the order winners. Thus, industries, regardless of the field, begin to search for new ways of enhancing their organizational performance and for identifying solutions for their business problems. In this regard, organizations are exploring the inclusion of workforce diversity against the traditional monolithic structure. Singapore's workforce has employees from different countries, cultures, generations and genders. This multiculturalism has positioned Singapore as an attractive foreign investment destination due to its mature and experienced workforce. The mix of competencies as a result of wider diversity offers a range of opportunities. Thus, workforce diversity is regarded as an asset for Singapore for connecting with business from all over the world and for enabling foreign communities to engage their business within its location.

Just as organizational performance is highly influenced by individual employee performance, the positive outcomes of workforce diversity at the employee level would also act as intrinsic as well as extrinsic motivational factors for them and would also increase employee participation. Therefore, this study focuses on the employee's perception gained through their personal experience in dealing with workforce diversity - with respect to age, gender and ethnicity in the context of their organisation in Singapore. It covers both service and manufacturing industries as the former is a relationship dominant while the latter is a task oriented. Past research findings indicate that diversity is beneficial to performance under facilitating contexts whereas it is detrimental under inhibiting contexts. In this regard, this study would provide the status of diversity in the working environment in Singapore. An attempt is also 
being made to identify potential solutions that the employees perceive to improve the benefit of workforce diversity to the next level.

\section{Problem Statement}

A good quality decision can be made from a wider choice of alternatives. When the organization has a conducive environment for practising workforce diversity, employees will enjoy all the positive benefits such as motivation, knowledge and skill transfer, creativity and better decision making (Amaram, 2007) and thus they will become catalysts for the organisation's growth. On the other hand, if workforce diversity is not handled correctly, the formation of various groups will occur; this could lead to miscommunication, emotional conflicts, power struggle and ultimately to high turnover of employees (Jackson et al, 1991; William and O'Reilly, 1998; Jehn, 1995). The diverse workforce will then become an inhibitor for organisation growth. Most of the studies reported in the literature had focused on exploring workforce diversity to improve organizational performance and leadership skills. In this regard, the views of employers and their upper management have been well documented. Very little attention has been paid to study the perception of employees for the inclusion of workforce diversity in their organization. Employees will appreciate and admire the implementation of diversity as a boon to their organization if it brings a positive impact on their performance. On the other hand, they criticize it as a white elephant if it impacts negatively on their performance.

\subsection{Research Questions}

The research questions are as follows:

1) What is the relationship between age diversity and employee performance in Singapore Organisations?

2) What is the relationship between gender diversity and employee performance in Singapore Organisations?

3) What is the relationship between ethnic diversity and employee performance in Singapore Organisations?

4) What is the relationship between workforce diversity and employee performance in Singapore Organisations?

\subsection{Hypothesis}

The practice of multi-generational work places offers mentoring advantages of organizational history, culture, accumulated knowledge and skills (Cremer, 1986). Some firms are utilizing older employees for their knowledge and experience, as mentors for the younger team members (Uschi and Stephan, 2013). Lazear (1999) found out that the advantages of age diversity can be gained only when organizations overcome the additional communication costs and issues related to emotional conflicts between them. Uschi and Stephen (2009) argued that age heterogeneity can negatively affect employee productivity due to differences in values and preferences of distinct age groups. Thus it is proposed:

\section{H1: There is a significant relationship between age diversity and employee performance}

A mix of cognitive abilities of men and women may enhance the organization's overall creativity and innovation (Hoffman, 1965; Maccoby and Jacklin, 1974). A gender diverse team produces high quality decisions over a homogeneous team (Rogelberg and Rumery, 1996). A positive relationship of gender diversity with performance would be anticipated based on a resource-based view of the firm whereas social identity and self-categorization theory would support a negative relationship (Mohammad et al, 2007). The negative side gender diversity slows down the decision making process due to internal conflicts (Jackson et al, 2003). Thus, it is proposed:

\section{H2: There is a significant relationship between gender diversity and employee performance}

The ethnically diverse teams were found to take better decisions than ethnically homogeneous teams (McLeod et al, 1996; Watson et al, 1993). However, there are also reports indicating that organizational diversity tends to reduce communication and coordination (Lazear, 1999; Morgan and Vardy, 2009) and increase employee turnover (Jackson, et al 1991). Ensher and Murphy (1997) had observed more likings and vocational support in the relationships of the same race than among cross race relationships. De et al, (2009) had concluded that ethnic diversity typically causes rejection of heterogeneous group members and reduced performance. Thus it is proposed:

\section{H3: There is a significant relationship between ethnic diversity and employee performance}

\section{Literature Review}

\subsection{Age Diversity}

Firms are not effectively utilizing the talents of old workers due to false assumptions and stereotypes that they are expensive, more prone to health problems, can't adapt to workplace changes and new technology, perform poorly, in 
comparison to their younger employees and are a poor return on training investment (Taylor, 2003; Davey, 2006; Davey and Cornwall, 2003; McGregor and Gray, 2002). The study on simple production technology by Barton (2004) indicated that teams with more diversity in age were significantly less productive. This finding is consistent with observations by Leonard and Levine (2003) that retail stores with greater age diversity among its employees tend to be less profitable. However, Ilmarinen (2005) had shown that there was no distinct connection between age and work performance. It is observed from many studies that older employees are as productive and as skilled as young ones. A heterogeneous age group of employees would therefore be more productive than a homogeneous age group (Williams and O'Reilly, 1998; Zenger and Lawrence, 1989).

\subsection{Gender Diversity}

Wood (1987) showed that mixed gender group performed better than the same gender group. McMillan-Capehart (2003) and Frink et al (2003) had explained the positive impact of gender diversity with organizational performance using resource based view. The studies examining the effects of gender diversity on group performance outcomes have found negative effects when the sample was male dominated and no effects when the sample was female dominated (Pelled, 1997). Gupta (2013) observed that moderate level of gender diversity increases competitive advantage while a higher level of gender diversity decreases organizational performance. Richard et al (2004) has observed an inverted U-shaped relationship between management group gender heterogeneity and productivity, with moderately heterogeneous management groups exhibiting better performance than gender homogeneous management groups. Similarly, results of a study by Frink et al (2003) demonstrated an inverted U-shaped relationship between gender composition and organization performance. Gender diversity showed a positive impact in the services industry and a negative impact on the manufacturing industry. Thus, services industries might benefit more from gender diversity than firms in the manufacturing industries. Therefore, high gender diversity will have a greater positive effect on performance in the services industry than in the manufacturing industry.

\subsection{Ethnic Diversity}

Ethnically diverse teams showed poor performance than homogeneous teams (Jackson et al, 2003). Jones (2005) and Jehn et al, (1999) found that groups were found to be less cohesive than teams; multiculturalism and diversity may have a less positive impact on group performance than team performance. The context of the workplace has significant influence over the impact of diversity on performance. Ethnically diverse teams lead to more creativity and innovation due to complementarities and learning opportunities (Alesina and La Ferrara, 2005; Lee and Nathan, 2011; Ozgen et al, 2011). A moderate level of ethnic diversity has no effect on the business outcomes of the teams namely sales, profit, \& market share whereas a high level of ethnic diversity improved business outcomes (Sander and Mirjam, 2012). A similar positive impact of ethnic diversity on sales, productivity, market share, and innovativeness was reported by Gupta (2013) and the team performance of the multidisciplinary teams in oil and gas industry by Van and Bunderson (2005). Ely (2004) has observed no relationship between ethnic diversity and sales revenue, customer satisfaction and sales productivity.

\section{Research Methodology}

The main objective of this research is to analyse the impact of workforce diversity on employee performance in Singapore organisations. The target population is the employees of both service and manufacturing sectors in Singapore. Employees in the service and manufacturing sectors are the target respondents. Two requirements have been set for the candidates to be qualified as the valid respondents:

1. Employees working in Singapore

2. Currently working in service and manufacturing sectors

Convenience sampling technique was used in this research as the sampling frame is irrelevant. Questionnaires were distributed to the valid respondents and they were requested to answer the questions. The population size was set to all the workforce in Singapore, regardless of their position or level, which is equivalent to 3.44 million in 2013(Labour Force, 2013) and the sample size was set to 316. The questionnaire was designed using the guidelines mentioned in the literature (Jill and Roger, 2009; Patrick and Rajkumar, 2012; Kossek and Zonia, 1993; Miller et al, 1998). The respondents were requested to provide their opinion in the scale of 1-5, (1) Strongly Disagree (SD), (2) Disagree (D), (3) Neutral (N), (4) Agree (A) and (5) Strongly Agree (SA). Pilot test was conducted with 18 respondents and the data were analysed using Statistical Package for Social Science (SPSS) software. The data from the pilot test are shown in Table 1. 
Table 1. Reliability test results

\begin{tabular}{llcc}
\hline No & Construct & Cronbach Alpha & No of items \\
\hline 1 & Age Diversity & 0.757 & 6 \\
\hline 2 & Gender Diversity & 0.722 & 6 \\
\hline 3 & Ethnic Diversity & 0.908 & 7 \\
\hline
\end{tabular}

The Cronbach alpha for age diversity, gender diversity and ethnic diversity was measured using 6,6 and 7 questions respectively. Cronbach alpha values estimated are higher than 0.70 , the internal consistency of the survey is found to be good. The data from the survey questionnaire were entered into Microsoft Excel and SPSS (Statistical Package for Social Sciences) software version 21 for data analysis.

\section{Results and Discussion}

The demographic profiles (namely age, gender, ethnicity, highest educational qualification attained, years of working experience and the type of industry they are serving) collected on the respondents are tabulated in Table 2.

Table 2. Demographic profile of the respondents

\begin{tabular}{|c|c|c|}
\hline Demographic profile & Frequency & Percentage \\
\hline \multicolumn{3}{|l|}{$\underline{\text { Age }}$} \\
\hline $20-29$ years & 87 & 27.53 \\
\hline $30-39$ years & 180 & 56.96 \\
\hline $40-49$ years & 29 & 09.18 \\
\hline 50 years and above & 20 & 06.33 \\
\hline Total & 316 & 100.00 \\
\hline \multicolumn{3}{|l|}{ Gender } \\
\hline Male & 201 & 63.61 \\
\hline Female & 115 & 36.39 \\
\hline Total & 316 & 100.00 \\
\hline \multicolumn{3}{|l|}{ Ethnicity } \\
\hline Ethnic Minority & 233 & 73.73 \\
\hline Ethnic Majority & 83 & 26.27 \\
\hline Total & 316 & 100.00 \\
\hline \multicolumn{3}{|l|}{ Educational qualification } \\
\hline Secondary School & 9 & 2.85 \\
\hline Diploma & 188 & 59.49 \\
\hline Bachelor Degree & 94 & 29.75 \\
\hline Master Degree & 25 & 7.91 \\
\hline Total & 316 & 100.00 \\
\hline \multicolumn{3}{|l|}{ Years of experience } \\
\hline$<$ 10years & 267 & 84.49 \\
\hline$>10$ years & 49 & 15.51 \\
\hline Total & 316 & 100.00 \\
\hline \multicolumn{3}{|l|}{ Type of industry } \\
\hline$<10$ years & 267 & 84.49 \\
\hline$>10$ years & 49 & 15.51 \\
\hline Total & 316 & 100.00 \\
\hline
\end{tabular}


The number of male respondents is about $27 \%$ higher than female respondents. The low response of females could be attributed to their un-willingness to respond and to the natural probability of getting the female employees is slightly lower than male counterpart as a result of $44 \%$ of female employees in Singapore workforce compares to $56 \%$ of male employees. About 267 respondents are less than 40 years old and 49 respondents are more than 40 years old. The respondents participated in the survey were Chinese, Malay and Indians. The ethnic majority classified in this research is Chinese whereas Malay and Indians are grouped as an ethnic minority. The majority of the respondents are diploma holders $(59.49 \%)$, followed by bachelor degree holders $(29.75 \%)$, master degree holders (7.91\%) and secondary school level (2.85\%). About $84.49 \%$ of respondents are working more than 10 years and $15.51 \%$ have work experience less than 10 years. About $68.67 \%$ of respondents are working in the manufacturing industry and $31.33 \%$ of them are in the service industry.

The percentage, mean and standard deviation estimated for the responses on the effect of age diversity in the workforce is tabulated in Table 3.

Table 3. Central tendencies measurement: age on employee performance

\begin{tabular}{clccccccc}
\hline No & \multicolumn{1}{c}{ Question } & $\begin{array}{c}\text { SD } \\
(\%)\end{array}$ & $\begin{array}{c}\mathrm{D} \\
(\%)\end{array}$ & $\begin{array}{c}\mathrm{N} \\
(\%)\end{array}$ & $\begin{array}{c}\text { A } \\
(\%)\end{array}$ & $\begin{array}{c}\text { SA } \\
(\%)\end{array}$ & Mean & $\begin{array}{c}\text { Std } \\
\text { Dev }\end{array}$ \\
\hline 1 & $\begin{array}{l}\text { The expertise of young employees with } \\
\text { high tech tools helps older employees to } \\
\text { improve their knowledge on the latest } \\
\text { technologies }\end{array}$ & 0.3 & 9.2 & 24.1 & 43.0 & 23.4 & 3.8 & 0.91 \\
\hline 2 & $\begin{array}{l}\text { The risk taken by younger employee } \\
\text { contributed to the success of the team }\end{array}$ & 0.3 & 8.9 & 25.9 & 51.3 & 13.6 & 3.69 & 0.83 \\
\hline $3 \quad \begin{array}{l}\text { The mentoring by older employees } \\
\text { benefited young employees in acquiring } \\
\text { job skills }\end{array}$ & 0.0 & 3.2 & 27.8 & 41.5 & 27.5 & 3.93 & 0.82 \\
\hline 4 & $\begin{array}{l}\text { Older employees mitigated the friction } \\
\text { among younger employees in the team and } \\
\text { promoted team cohesiveness }\end{array}$ & 0.9 & 7.3 & 34.8 & 41.5 & 15.5 & 3.63 & 0.86 \\
\hline 5 & $\begin{array}{l}\text { No emotional conflicts and anxiety within } \\
\text { the team due status difference between } \\
\text { young and old employees }\end{array}$ & 1.3 & 17.1 & 32.0 & 30.7 & 19.0 & 3.49 & 1.03 \\
\hline 6 & $\begin{array}{l}\text { I did not experience stress in the last 12 } \\
\text { months due to age diversity issues in my } \\
\text { work place }\end{array}$ & 0.0 & 10.4 & 35.8 & 35.9 & 14.9 & 3.58 & 0.87 \\
\hline
\end{tabular}

Source: Data generated using SPSS version 21

About $43 \%$ of the respondents agree that they received benefit from the expertise of young employees on high technology whereas $23.1 \%$ strongly agree and $24.1 \%$ are neutral with the fact. Reverse mentoring is becoming popular in the last few years in the corporate world - an innovative HR strategy where the young employees mentor their seasoned managers (Charles, 2007). The majority of the respondents accept the contribution from the risk taken by younger employees whereas only $9 \%$ disagree with that fact. Younger employees are more risk takers than older employees (Sproten and Schwieren, 2012) and the risk taking tendency decreases with age (Julia et al, 2004). The advantage of mentoring by older employees during orientation has been well accepted by over $69 \%$, while only $3.2 \%$ disagree. Older employees are regarded as knowledge bearers of organisations (Cremer, 1986). Uschi and Stephan (2013) claim that more effective transfer of specific know-how and cultural values from older to younger generations as one of the benefits of age diversity.

The mitigation role played by the older employees during the friction in the team has been recognized by $57 \%$, whereas $7.3 \%$ disagree and $34.8 \%$ remain neutral. Older employees have a balance of socio-emotional and cognitive capability that helps them to counsel the younger employees (Megan, 2014). About 17.1\% has disagreed about the absence of emotional conflicts and anxiety in the team due to age difference of employees whereas $30.7 \%$ agree, $19 \%$ strongly agree and 30.7\% remain neutral. Milliken (1996) has reported empirical evidence that higher age diversity leads to difficult and less frequent communication within the team. Emotional (affective) conflicts lead to anger, distrust, fear, frustration, and other forms of negative affect (Pelled, 1996). The high standard deviation 1.87 observed for this question reflects the higher difference of opinion among the respondents. It seems that emotional conflict issues have been perceived by the highest percentage of respondents $(17.1 \%)$ as the negative impact of age 
diversity. Interestingly, majority of the respondents (35.9\% agree \& $14.9 \%$ strongly agree) did not experience any stress related to age diversity in the work place while a small population of $10.4 \%$ disagreed. The generation gap resulted in age diversity might also lead to conflicts, dissatisfaction and ultimately to employee turn-over (Lau and Murnighan, 2005; Richard and Shelor, 2002; Peeters and Van, 2008).

The mean value of all questions is in the range of $3.49-3.93$ and the standard deviation is $0.82-1.03$. The highest mean value (3.93) is observed for mentoring benefit by age diversity whereas the lowest mean value (3.49) is observed for emotional conflicts due to age diversity.

Table 4. Central tendencies measurement: gender on employee performance

\begin{tabular}{|c|c|c|c|c|c|c|c|c|}
\hline No & Question & $\begin{array}{l}\mathrm{SD} \\
(\%)\end{array}$ & $\begin{array}{c}\mathrm{D} \\
(\%)\end{array}$ & $\begin{array}{c}\mathrm{N} \\
(\%)\end{array}$ & $\begin{array}{c}\mathrm{A} \\
(\%)\end{array}$ & $\begin{array}{l}\text { SA } \\
(\%)\end{array}$ & Mean & $\begin{array}{l}\text { Std } \\
\text { Dev }\end{array}$ \\
\hline 1 & $\begin{array}{l}\text { As women tend to be a good listener and } \\
\text { men tend to be aggressive, a balanced } \\
\text { work force of both sex offers the best } \\
\text { solution of both worlds }\end{array}$ & 0.0 & 18.0 & 23.1 & 45.9 & 13.0 & 3.54 & 0.93 \\
\hline 2 & $\begin{array}{l}\text { The transformational leadership style (help } \\
\text { each other by give and take policy) of the } \\
\text { female employee contributed to the } \\
\text { success of the team }\end{array}$ & 0.0 & 14.6 & 29.7 & 39.9 & 15.8 & 3.57 & 0.93 \\
\hline 3 & $\begin{array}{l}\text { Gender diverse teams showed better } \\
\text { problem solving and decision making } \\
\text { skills than gender homogeneous teams }\end{array}$ & 0.3 & 3.8 & 22.5 & 57.0 & 16.5 & 3.85 & 0.74 \\
\hline 4 & $\begin{array}{l}\text { Gender diversity is an asset for our } \\
\text { corporate image and brand value }\end{array}$ & 0.0 & 21.2 & 19.6 & 50.0 & 9.2 & 3.47 & 0.93 \\
\hline 5 & $\begin{array}{l}\text { Gender diverse teams achieved targets due } \\
\text { to the good relationship and effective } \\
\text { communication }\end{array}$ & 0.0 & 8.9 & 34.8 & 45.9 & 10.4 & 3.58 & 0.76 \\
\hline 6 & $\begin{array}{l}\text { I did not experience stress in the last } 12 \\
\text { months due to gender diversity issues in } \\
\text { my work place }\end{array}$ & 0.0 & 9.8 & 20.6 & 49.4 & 29.3 & 3.80 & 0.87 \\
\hline
\end{tabular}

Source: Data generated using SPSS version 21

Table 4 shows the percentage, mean and standard deviation estimated for the responses on the effect of gender diversity. About $45.9 \%$ has agreed that the balance of both genders is good for team progress whereas $18.0 \%$ disagreed with that. Research on female leadership behaviours indicates that women tend to adopt more accommodative strategies than their male counterparts (Brad, 1975). The positive impact of female leadership has been recognized by $55.7 \%$ (39.9\% agree \& $15.8 \%$ strongly agree) while $14.6 \%$ disagree and $29.7 \%$ have no comments. Among all the questions, the problem solving and decision making advantage of gender diversity has received the highest score $57 \%$ as agree and the lowest score $3.8 \%$ as disagree. The blend of cognitive abilities of both men and women will enhance the innovation, creativity and quality of decision making (Maccoby and Jacklin, 1974; Rogelberg and Rumery, 1996). About $21.2 \%$ had disagreed to perceive gender diversity as corporate image and brand value while $50 \%$ have agreed. Having more women on the board of directors has increased corporate ratings and reputation (Bernadi et al, 2006; Stephen et al, 2010). Gender diversity has been viewed as an effective tool for achieving targets by $56.3 \%$ (45.9\% agree and $10.4 \%$ strongly agree) and $34.8 \%$ remained neutral and $8.9 \%$ disagreed. In gender balanced teams, there are more opportunities for males and females to interact with each other. The increased contact may weaken social identities and eliminate the undesirable in-group out-group dynamics and performance could improve (Fields and Blum, 1997; Rogelberg and Rumery, 1996). Most of the respondents did not face any gender related stress issues in the work place (49.4\% agree \& $29.3 \%$ strongly agree), but still a small population of the workforce, about 9.8\%, had felt gender related stress issues. Messick and Mackie (1989) postulated 
that self-categorisation based on gender will lead to psychological groups of males and females that will trigger in-group and out-group dynamics. This will decrease cohesion (Triandis et al, 1994) and increase conflicts (Pelled, 1996) among team members.

The mean value of all questions is in the range of $3.47-3.85$ and the standard deviation is $0.74-0.93$. The highest mean value (3.85) is observed for problem solving skills by gender diversity whereas the lowest mean value (3.47) is observed for considering gender diversity as corporate image and brand value.

Table 5. Central tendencies measurement: ethnicity on employee performance

\begin{tabular}{|c|c|c|c|c|c|c|c|c|}
\hline No & Question & $\begin{array}{l}\mathrm{SD} \\
(\%)\end{array}$ & $\begin{array}{c}\mathrm{D} \\
(\%)\end{array}$ & $\begin{array}{c}\mathrm{N} \\
(\%)\end{array}$ & $\begin{array}{c}\mathrm{A} \\
(\%)\end{array}$ & $\begin{array}{l}\text { SA } \\
(\%)\end{array}$ & Mean & $\begin{array}{c}\text { Stdd } \\
\text { ev }\end{array}$ \\
\hline 1 & $\begin{array}{l}\text { The ethnic diversity in our team has } \\
\text { enabled to find a creative solution }\end{array}$ & 1.6 & 3.5 & 31.3 & 44.6 & 19.0 & 3.76 & 0.85 \\
\hline 2 & $\begin{array}{l}\text { The ethnic diversity in our team has } \\
\text { improved the quality of decision making }\end{array}$ & 0.0 & 6.3 & 33.9 & 35.1 & 24.7 & 3.78 & 0.89 \\
\hline 3 & $\begin{array}{l}\text { The ethnic diversity promoted healthy } \\
\text { competition in the team and contributed to } \\
\text { outstanding achievements }\end{array}$ & 0.0 & 5.4 & 27.5 & 51.3 & 15.8 & 3.78 & 0.78 \\
\hline 4 & $\begin{array}{l}\text { The ethnic diversity in our team promoted } \\
\text { free flow of information between ethnic } \\
\text { groups }\end{array}$ & 0.0 & 12.0 & 24.4 & 41.1 & 22.5 & 3.74 & 0.94 \\
\hline 5 & $\begin{array}{l}\text { The ethnic diversity did not affect the } \\
\text { professional relationship with the team }\end{array}$ & 0.0 & 6.6 & 47.8 & 37.3 & 8.2 & 3.47 & 0.74 \\
\hline 6 & $\begin{array}{l}\text { The ethnic diversity in our team helped to } \\
\text { expedite the completion of our } \\
\text { task/projects on time }\end{array}$ & 0.6 & 3.5 & 41.5 & 44.0 & 10.4 & 3.60 & 0.75 \\
\hline 7 & $\begin{array}{l}\text { I did not experience stress in the last } 12 \\
\text { months due to ethnic diversity issues in my } \\
\text { work place }\end{array}$ & 4.7 & 22.2 & 19.0 & 36.7 & 17.4 & 3.4 & 1.15 \\
\hline
\end{tabular}

Source: Data generated using SPSS version 21

About 63.6\% (44.6\% agree and 19\% strongly agree) had accepted ethnic diversity as an effective tool for finding creative solutions whereas $31.3 \%$ remained neutral and $5.1 \%$ (3.5\% disagree and $1.6 \%$ strongly disagree) disagreed with the fact. O'Reilly et al (1998) showed that ethnic diversity promotes creativity and implementation of new ideas over homogeneous teams. About 59.8\% (35.1\% agree and $24.7 \%$ strongly agree) had believed ethnic diversity had improved decision making and 6.3\% did not have that faith. McLeod et al (1996) and Watson et al (1993) have found that ethnically diverse work teams make better decisions than homogeneous teams. Very few (5.4\%) had disagreed with the contribution of ethnic diversity for outstanding achievements while $67.1 \%(51.3 \%$ agree and $15.8 \%$ strongly agree) recognized the achievements possible with ethnic diversity. Multicultural teams will lead to a winning mentality when moderated in constructive (task) conflicts (Jehn et al, 1999; Kochan et al, 2003). About $63.6 \%$ (41.5\% agree and $22.5 \%$ strongly agree) had a perception that ethnic diversity promotes free flow of information while $24.4 \%$ remained neutral and $12 \%$ disagree with that belief. Due to social categorization, ethnic diversity will lead to less coordination and thus difficult communication (Lazear, 1999; Morgan and Vardy, 2009). $47.8 \%$ had neither agreed nor disagreed about the impact of ethnic diversity on the professional relationship with employees. However, $6.6 \%$ had a belief that ethnic diversity negatively impact the professional relationship and $45 \%$ (37.3\% agree and $8.2 \%$ strongly agree) thought that there is no impact. $54.4 \%$ (44\% agree and $10.4 \%$ strongly agree) have agreed that ethnic diversity had helped to meet the timeline of projects whereas $41.5 \%$ had no comments and 3.5\% did not agree with that. Amaram (2007) states that ethnic diversity can lead to dysfunctional conflicts, reduced psychological identification, and guarded communication, and thus become counterproductive. The resultant confusion could create delays in project completion. About $26.9 \%$ (4.7\% strongly disagree and $22.2 \%$ disagree) had 
gone through stress due to ethnic diversity whereas 19\% remained neutral and $54.1 \%$ (36.7 agree and 17.4\% strongly agree) did not face any ethnic diversity stress issues. As organizations and institutions become more ethnically diverse, racial or ethnic harassment may become more frequent and may result in multiple negative outcomes. The targets of ethnic harassment may disengage from the work situation physically or psychologically (Kimberly et al, 2000). The highest standard deviation 1.15 among all the questions reveals that the respondents had a wide difference of opinion about the ethnic diversity related stress issues, probably contributed by individual organizational practice of ethnic diversity. The mean value of all questions is in the range of 3.40 -3.78 and the standard deviation is 0.74-1.15. The highest mean value (3.78) is observed for influence of decision making and the contribution to the achievements by ethnic diversity whereas the lowest mean value (3.40) is observed for considering ethnic diversity related stress issues. The Pearson correlation coefficient estimated for the age diversity is given in Table 6 .

Table 6. Pearson coefficient of age diversity

\begin{tabular}{clcc}
\hline & Age group & Employee performance \\
\hline Age of the employee & Pearson correlation & 1 & -0.011 \\
& Significance (2 tailed) & & 0.846 \\
$\mathrm{~N}$ & 316 & 316 \\
\hline Employee performance Pearson correlation & -0.011 & 1 \\
& Significance (2 tailed) & 0.846 & 316 \\
$\mathrm{~N}$ & 316 &
\end{tabular}

Source: Data generated using SPSS version 21

H1: There is no significant relationship between age diversity and employee performance

Based on the results, there is a negative relationship (-0.011) between age group of employees and their performance. The value of correlation coefficient (-0.011) falls in the range of 0 to -0.19 which is interpreted as "very low and almost negligible". The significance of the relationship is 0.846 which is greater than 0.05 . Thus, the null hypothesis is accepted that there is no significant relationship between age diversity and employee performance. Even though age is one of the characteristics of the employee that triggers categorization among them, we observed there is no influence of age diversity on the employee performance which agrees with the findings discussed in Williams and O'Reilly (1998) and Jackson et al (2003). The Pearson correlation coefficient estimated for the gender diversity is given in Table 7.

Table 7. The Pearson coefficient of gender diversity

\begin{tabular}{|c|c|c|}
\hline & Gender of employee & Employee performance \\
\hline Gender of the employee Pearson correlation & 1 & 0.032 \\
\hline Significance (2 tailed) & & 0.572 \\
\hline $\mathrm{N}$ & 316 & 316 \\
\hline Employee performance Pearson correlation & 0.032 & 1 \\
\hline Significance (2 tailed) & 0.572 & \\
\hline $\mathrm{N}$ & 316 & 316 \\
\hline
\end{tabular}

Source: Data generated using SPSS version 21

$\mathrm{H} 2$ : There is no significant relationship between gender diversity and employee performance

Based on the results, there is a positive relationship (0.032) between gender of employees and their performance. The value of correlation coefficient $(0.032)$ falls in the range of 0 to 0.19 which is interpreted as "very low and almost negligible". The significance of the relationship is 0.572 which is greater than 0.05 . Thus, the null hypothesis is accepted that there is no significant relationship between gender diversity and employee performance. Similar to our observation, there are many reports that observed non- significant impact of gender diversity (Balkundi et al, 2006; Ely, 2004; Graves and Elsass, 2005; Hobman and Bordia, 2006; Leonard and Levine, 2006). The Pearson correlation coefficient estimated for the ethnic diversity is given in Table 8 . 
Table 8 . The Pearson coefficient of ethnic diversity

\begin{tabular}{ccc}
\hline & $\begin{array}{c}\text { Ethnic status of } \\
\text { employee }\end{array}$ & Employee performance \\
\hline Ethnic status of the employee Pearson correlation & 1 & -0.012 \\
Significance (2 tailed) & 316 & 0.829 \\
$\mathrm{~N}$ & -0.012 & 316 \\
\hline Employee performance Pearson correlation & 0.829 & 1 \\
Significance (2 tailed) & 316 & 316 \\
$\mathrm{~N}$ & & \\
\hline
\end{tabular}

Source: Data generated using SPSS version 21

H3: There is no significant relationship between ethnic diversity and employee performance

Based on the results, there is a negative relationship (-0.012) between the ethnic status of employees and their performance. The value of correlation coefficient $(-0.012)$ falls in the range of 0 to -0.19 which is interpreted as "very low and almost negligible". The significance of the relationship is 0.829 which is greater than 0.05 . Thus, the null hypothesis is accepted that there is no significant relationship between ethnic diversity and employee performance. Jehn and Bezrukova (2004) had also reported a non-significant relationship of ethnic diversity on team performance. Joshi and Roh (2007) had also reported more null findings (20) than positive (7) or negative effects (8) of ethnic diversity. Webber and Donahue (2001) in their meta-analysis of 24 studies found that race or ethnicity had no relationship with team cohesion or performance. The organizational strategies of individual companies are likely to have an influence on the impact of workforce diversity. Growth and customer oriented strategies have a positive impact; whereas stability oriented growth strategies have a negative impact of workforce diversity on organizational performance.

Growth-oriented strategies require new ideas, experimentation, and creative processes and thus make possible the inclusion of views and efforts from a diverse employee population (Oliver, 1990; Watson et al, 1993; Lumpkin and Dess, 1996). Customer oriented strategies can benefit from utilizing the information of diverse employees to better serve the needs of their customers (Jackson and Alvarez, 1992; Thomas and Ely, 1996). Stability-oriented strategic environments are not expected to benefit from diversity. Groups in such environments demand less innovation and focus more on efficiency achieved through centralization, specification, and vertical differentiation (Doty et al. 1993). For these groups, diversity could decelerate group processes, increase communication problems and misunderstanding, and hinder the speed and proficiency of decision-making processes (Milliken and Martins, 1996; Williams and O'Reilly, 1998). The nature of the task will also have an impact on workforce diversity. The routine task is characterised by standard, less innovation and high coordination process that gained very little or nothing about diversity related competencies. In contrast, innovative and creative tasks are associated with complex problem solving capabilities; diversity will be beneficial to them.

People-oriented cultures will cultivate a sense of cooperation and teamwork which may reduce intragroup bias arising from demographic differences (Gaertner et al, 1990; Tsui et al, 1992). Competition-oriented cultures place greater emphasis on individual accomplishment as opposed to collective accomplishment, and may cause group members to seek differences amongst themselves ( $\mathrm{Ng}$ and Van, 2001). This desire clearly escalates differences between those from diverse backgrounds that may be detrimental to the efficient functioning of individuals within the group and the group as a whole (Mannix et al, 2001; Tsui et al, 1992). Thus, the benefits of workforce diversity observed in one organization might have been compensated by the limitations of workforce diversity in other organizations as a result of different organizational strategies, culture and the nature of the task undertaken by each organization.

\section{Conclusion}

The study reveals that the diversity of all three demographic profiles of the workforce - namely age, gender and ethnicity - does not significantly impact the performance of employees. Thus it is concluded that the employees in Singapore neither admire the workforce diversity as a boon to them nor do they criticise it as a white elephant and they have shown a neutral perception about workforce diversity. It is believed that organization culture, human resource practices, nature of work and business strategy of individual firms are different from each other and the differences are likely to mask the impact of variables on the employee performance in one firm with that observed in 
other firm. Recommendations based on the perspectives of employees for improving the effectiveness of workforce diversity have also been made. A comparison of the effect of workforce diversity on similar or the same organizations operating in different countries would improve the depth of knowledge, especially on the interaction of organizational culture and national environment, and the effect of workforce diversity further. For further understanding, a study can focus on a specific category (positions in the organization like Directors, Managers or Executives) of employees.

\section{References}

Alesina, A., \& La Ferrara, E. (2005). Ethnic diversity and economic performance. Journal Economic Literature, 43, 762-800. http://dx.doi.org/10.1257/002205105774431243

Amaram, D. I. (2007). Cultural diversity: Implications for workplace management. Journal of Diversity Management, 2(4), 1-6.

Balkundi, P., Kilduff, M., Barsness, Z. I., \& Michael, J. H. (2006). Demographic antecedents and performance consequences of structural holes in work teams. Journal of Organizational Behaviour, 28(2), 241-260. http://dx.doi.org/10.1002/job.428

Barton Hamilton., J. A., \& Nickerson, H. Owan. (2004). Diversity and productivity in production teams. Working Paper, Washington University, St. Louis.

Bernardi, R., S. Bosco., \& K. Vassill. (2006). Does female representation on boards of directors associate with fortune's 100 Best companies to work for list?. Business and Society, 45(2), 235-248. http://dx.doi.org/10.1177/0007650305283332

Brad Chapman, J. (1975). Comparison of male and female leadership styles. Academy of Management Journal, 18(3), 645-650. http://dx.doi.org/10.2307/255695

Charles, Wonderlic. (2007). Reverse mentoring, old dogs, new tricks. Retrieved 16 March 2014, from http://www.hr.com/SITEFORUM

Cremer, J. (1986). Cooperation in on going organizations. The Quarterly Journal of Economics, 101(1), 33-50. http://dx.doi.org/10.2307/1884640

Davey, J. (2006). The labour market. In Boston and Davey (Eds.), Implications of Population Ageing Opportunities and Risks. Institute of Policy Studies, Victoria University, Wellington.

Davey, J., \& Cornwall, J. (2003). Maximising the potential of older workers. NZIRA Future Proofing New Zealand Series, New Zealand Institute for Research on Ageing, Victoria University, Wellington.

De Drew, C. K. W., Bechthold, M. N., \& Nijstad, B. A. (2009). Diversity and the creative capacity of organizations and teams. Position Article Research Task 3.2 on SustainableDevelopment in a Diverse World, University of Amsterdam, the Netherlands, pp.1-26.

Doty, D. H., Glick, W. H., \& Huber, G. P. (1993). Fit, equifinality and organizational effectiveness: a test of two configurational theories. Academy of Management Journal, 36, 1196-1250. http://dx.doi.org/10.2307/256810

Ely, R. J. (2004). A field study of group diversity, participation in diversity education programs, and performance. Journal of Organizational Behaviour, 25, 755-780. http://dx.doi.org/10.1002/job.268

Ensher, E. A., \& Murphy, S. E. (1997). Effects of race, gender, perceived similarity, and contact on mentor relationships. Journal of Vocational Behaviour, 50(3), 460-481. http://dx.doi.org/10.1006/jvbe.1996.1547

Fields, D.L., \& Blum T.C. (1997). Employee satisfaction in work groups with different gendercomposition. Journal

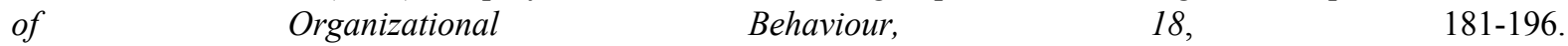
http://dx.doi.org/10.1002/(SICI)1099-1379(199703)18:2<181::AID-JOB799>3.0.CO;2-M

Frink, D. D., Robinson, R. K., Reithel, B., Arthur, M. M., Ammeter, A. P., Ferris, G. R., ... Morristte, H. S. (2003). Gender demography and organizational performance: A two-study investigation with convergence. Group and Organization Management, 28, 127-147. http://dx.doi.org/10.1177/1059601102250025

Gaertner, S., Mann, J., Dovidio, J., \& Murrel, A. (1990). How does cooperation reduce intergroup bias?. Journal of Personality and Social Psychology, 59, 692-704. http://dx.doi.org/10.1037/0022-3514.59.4.692

Graves, L. M., \& Elsass, P. M. (2005). Sex and sex dissimilarity effects in on going teams: some surprising findings. Human Relations, 58(2), 191-221. http://dx.doi.org/10.1177/0018726705052181 
Gupta, R. (2013). Workforce diversity and organizational performance. International Journal of Business and Management Invention, 2(6), 36-41.

Hobman, E. V., \& Bordia, P. (2006). The role of team identification in the dissimilarity-conflict relationship. Group Processes and Intergroup Relations, 9(4), 483-507. http://dx.doi.org/10.1177/1368430206067559

Hoffman, R. (1965). Group problem solving. In Berkowitz L. (Ed.), Advances in Experimental Social Psychology, (Vol.49, pp.99-132). Academic Press, New York.

Ilmarinen, J. (2005). Towards a longer work life! Ageing and the quality of work life in the European Union. Finnish Institute of Occupational Health, Ministry of Social Affairs and Health, Helsinki.

Jackson, S. E., \& Alvarez, E. B. (1992). Working through diversity as a strategic imperative. In D. W. Bray (Ed.), Diversity in the work place (pp. 13-36). New York, NY: Guilford Press.

Jackson, S.E., Brett J.F., Sessa, V.I., Cooper D.M., Julin, J.A., \& Peyronnin, K. (1991). Some differences make difference: Individual dissimilarity and group heterogeneity correlates of recruitment, promotions and turnover. Journal of Applied psychology, 76, 675-689. http://dx.doi.org/10.1037/0021-9010.76.5.675

Jackson, S.E., Joshi, A., \& Erhardt, N.L. (2003). Recent research on team and organizational diversity: SWOT analysis and implications. Journal of Management, 29, 801-30. http://dx.doi.org/10.1016/S0149-2063(03)00080-1

Jehn, K., \& Bezrukova, K. (2004). A field study of group diversity, group context, and performance. Journal of Organizational Behaviour, 25(6), 703-729. http://dx.doi.org/10.1002/job.257

Jehn, Karen A., Gregory, B., North, Craft, \& Margaret, A. Neale. (1999). Why differences make a difference: A field study and diversity, conflict, and performance. Administrative Science Quarterly, 44(4), 741-763. http://dx.doi.org/10.2307/2667054

Jehn, K.A. (1995). A multi method examination of the benefits and the detriments of intragroup conflict. Administrative science Quarterly, 40, 256-282. http://dx.doi.org/10.2307/2393638

Jill, Collis, \& Roger, Hussey. (2009). Business Research ( $3^{\text {rd }}$ ed.). Palgrave MacMillan UK, pp.188.

Jones, B.F. (2005). Age and great invention. NBER Working Papers 11359. Retrieved 1 April 2014, from http://www.nber.org/papers/w11359.pdf?new_window=1

Joshi, A., \& Roh, H. (2007). Context matters: a multilevel framework for work team diversity research. In J. Martocchio (Ed.), Research in Personnel and HumanResource Management (Vol. 26, pp.1-48). Greenwich, CT: JAI Press.

Julia, Deakin, Michael, Aitken, T.R., Ever, Robbins, \& Barbara, Sahakian. (2004). Risk taking during decision-making in normal volunteers changes with age. Journal of the International Neuropsychological Society, 10(4), 590-598. http://dx.doi.org/10.1017/S1355617704104104

Kimberly, T., Schneider, Robert T. Hitlan, \& Phanikiran, Radhakrishnan. (2000). An Examination of the Nature and Correlates of Ethnic Harassment Experiences in Multiple Contexts. Journal of Applied Psychology, 85(1), 3-12. http://dx.doi.org/10.1037/0021-9010.85.1.3

Kochan, T., Bezrukova, K., Ely, R., Jackson, S., Joshi, A., Jehn, K., ... Thomas, D. (2003). The effects of diversity on business performance: Report of theDiversity Research Network. Sloan Management Review, 42(1), 3-2.

Kossek, E.E., \& Zonia, S.C. (1993). Assessing diversity climate: A field study reactions to employer efforts to promote diversity. Journal of Organizational Behaviour, 14, 61-81. http://dx.doi.org/10.1002/job.4030140107

Lau, Dora C., \& J. K. Murnighan. (2005). Interactions within groups and subgroups: The effects of demographic faultlines. Academy of Management Journal, 48(4), 645-659. http://dx.doi.org/10.5465/AMJ.2005.17843943

Lazear, E. P. (1999). Globalisation and the Market for Team-Mates. The Economic Journal, 109(454), 15-40. http://dx.doi.org/10.1111/1468-0297.00414

Lee, N., \& Nathan, M. (2011). Does cultural diversity help innovation in cities: evidence from London firms. LSE Research Online Documents on Economics 33579, London School of Economics and Political Science, LSE Library.

Leonard, J. S., \& Levine, D. (2003). Diversity, Discrimination and Performance, pp.40, California: Institute for Research on Labour and Employment, UC Berkeley. 
Leonard, J., \& Levine, D. (2006). The effect of diversity on turnover: a large case study. Industrial and Labour Relations Review, 59, 547-572.

Lumpkin, G. T., \& Dess, G. G. (1996). Clarifying the entrepreneurial orientation construct and linking it to performance. Academy of Management Review, 21, 135-172.

Maccoby, E.E., \& Jacklin. C.N. (1974). The psychology of sex differences. Stanford University Press, Stanford.

Mannix, E. A., Thatcher, S., \& Jehn, K. A. (2001). The dynamic nature of conflict: a longitudinal study of intragroup conflict and group performance. Academy of Management Journal, 44, 238-251. http://dx.doi.org/10.2307/3069453

McGregor, J., \& Gray, L. (2002). Stereotypes and older workers: the New Zealand experience. Social Policy Journal of New Zealand, 18, 163-177.

McLeod, P. L., Lobel, S., \& Cox, T. H. (1996). Ethnic diversity and creativity in small groups. Small Group Research, 27, 248-264. http://dx.doi.org/10.1177/1046496496272003

McMillan-Capehart, A. (2003). Cultural diversity's impact on firm performance: The moderating influence of diversity initiatives and socialization tactics. Unpublished doctoral dissertation, Louisiana Tech University, USA.

Megan Lokteff. (2014). The Brains of Emerging Adults, Risk Taking, and the Consequences for Camps. Retrieved 16 March 2014, from www.acacamps.org/campmag/1009

Messick, D, M., \& Mackie, D.M. (1989). Intergroup relations. Annual Review of Psychology, 40, 45-81. http://dx.doi.org/10.1146/annurev.ps.40.020189.000401

Miller, C.C., Linda, Burke, M., \& William, H. Glick. (1998). Cognitive diversity among upper-echelon executives: Implications for strategic decision process. Strategic Management Journal, 19, 39-58. http://dx.doi.org/10.1002/(SICI)1097-0266(199801)19:1<39::AID-SMJ932>3.0.CO;2-A

Milliken, Frances J., \& L. L. Martin. (1996). Searching for Common Threads: Understanding the Multiple Effects of Diversity in Organizational Groups. The Academy of Management Review, 21(2), 402-433.

Mohammad Ali, Isabel, Metz, \& Kulik, C.T. (2007). Workforce gender diversity: Is it a source of competitive advantage?. 21st ANZAM conference, Sydney, Australia.

Morgan, J., \& Vardy, F. (2009). Diversity in the workplace. The American EconomicReview, 99(1), 472-485. http://dx.doi.org/10.1257/aer.99.1.472

Ng, K. Y., \& Van Dyne, L. (2001). Culture and minority influence: effects on persuasion and originality. In C. K.W. De Dreu., and N. K. De Vries, (Eds.), Group Consensus and Minority Influence: Implications for Innovation (pp. 284-306). Malden, MA: Blackwell.

O’Reilly, C.A., Williams, K.Y., \& Barsade, S.G. (1998). Group democracy and innovation: Does diversity help?. In E Mannix., and M.Neale. (Eds.), Research in the management of groups and teams, (Vol. 1, pp.183-207). Greenwich, C.T, JAI Press.

Oliver, C. (1990). Determinants of inter organizational relationships: integration and future directions. Academy of Management Review, 15, 241-265.

Ozgen, C., Nijkamp, P., \& Poot, J. (2011). The impact of cultural diversity on innovation: Evidence from Dutch RM-level data. IZA Discussion Papers.

Patrick, H.A., \& Raj Kumar, V. (2012). Managing Workplace Diversity: Issues and Challenge. http://dx.doi.org/10.1177/2158244012444615

Peeters, M., \& Van Emmerik, H. (2008). An introduction to the work and well-being of older workers. Journal of Managerial Psychology, Special Issue on Work and Wellbeing of Older Workers, 23(4), 353-363.

Pelled, L.H. (1996). Demographic diversity, conflict, and work group outcomes: An intervention process theory. Organization Science, 7, 615-631. http://dx.doi.org/10.1287/orsc.7.6.615

Pelled, L.H. (1997). Relational demography and perceptions of group conflict and performance. International Journal of Conflict Resolution, 22(1), 54-57.

Richard, O. C., \& Shelor, R. M. (2002). Linking top management team age heterogeneity to firm performance: Juxtaposing two mid-range theories. International Journal of Human Resource Management, 13(6), 958-974. 
Richard, O. C., Barnett, T., Dwyer, S., \& Chadwick, K. (2004). Cultural diversity in management, firm performance, and the moderating role of entrepreneurial orientation dimensions. Academy of Management Journal, 47(2), 255-266. http://dx.doi.org/10.2307/20159576

Rogelberg, S.G., \& Rumery, S.M. (1996). Gender diversity, team decision quality, time on task, and interpersonal cohesion. Small Group Research, 27, 79-90. http://dx.doi.org/10.1177/1046496496271004

Sander Hoogendoorn, \& Mirjam Van Praag. (2012). Ethnic diversity and team performance: A field experiment. Tinbergen Institute Discussion Papers 12-068/3, Tinbergen Institute.

Sproten, A.C., \& Schwieren, C. (2012). Age differences in the reaction to incentives-Do older people avoid competition?. Discussion paper series: 522. Retrieved 31 January 2014, from www.uni-heidelberg.de/md/awi/forschung/dp522_sproten_schwierren.pdf

Stephen, Bear, Noushi, Rahman, \& Corinne, Post. (2010). The Impact of board diversity and gender composition on corporate social responsibility and firm reputation. Journal of Business Ethics, 97, 207-221.

Taylor, P. (2003). Global ageing - meeting the business challenges. Paper prepared for symposium: An Ageless Workforce - Opportunities for Business, Sydney, $27^{\text {th }}$ August.

Tempest, S., Barnatt, C., \& Coupland, C. (2002). Grey advantage: New strategies for the old. Long Range Planning, 35, 475-492. http://dx.doi.org/10.1016/S0024-6301(02)00102-4

Thomas, D. A., \& Ely, R. (1996). Making differences matter: a new paradigm in managing diversity. Harvard Business Review, 74, 79-91.

Triandis, H.C., Kurowski, L.L., \& Gelfand, M.J. (1994). Workplace diversity. In Dunnette M.D., and Hough L.M.(Eds.), Handbook of industrial and organizational psychology (Vol. 4, pp.769-827). Consulting Psychologists Press, Palo Alto.

Tsui, A. S., Egan, T. D., \& O’Reilly, C. (1992). Being different: relational demography and organizational attachment. Administrative Science Quarterly, 37, 549-577. http://dx.doi.org/10.2307/2393472

Uschi Backes-Gellner, \& Stephan Veen. (2013). Positive effects of ageing and age diversity in innovative companies - Large-scale empirical evidence on company productivity. Human Resource Management Journal, 23(3), 279-295. http://dx.doi.org/10.1111/1748-8583.12011

Uschi Backes-Gellner, \& Veen Stephen. (2009). The Impact of aging and age diversity on company performance. WorkingPaper, 78, University of Zurich. Retrieved 30 March 2014, from http://www.zora.uzh.ch/

Van Der Vegt, G. S., \& Bunderson, S. J. (2005). Learning and performance in multidisciplinary teams: The importance of collective team identification source. Academy of Management Journal, 48, 532-547.

Watson, W., Kumar, K., \& Michaelsen, L. (1993). Cultural diversity's impact on interaction process and performance: comparing homogenous and diverse task groups. Academy of Management Journal, 36, 590-602.

Webber, S.S., \& Donahue, L.M. (2001). Impact of highly and less job-related diversity on work group cohesion and performance: A meta-analysis. Journal of Management, 27, 141-162. http://dx.doi.org/10.1016/S0149-2063(00)00093-3

Williams, K., \& O'Reilly, C. (1998). Demography and diversity in organizations: A review of 40 years of research. Research in Organizational Behaviour, 20, 77-140.

Wood, W. (1987). Meta analytical review of sex differences in group performance. Psychological bulletin, 102, 53-71. http://dx.doi.org/10.1037/0033-2909.102.1.53

Zenger, Todd R., \& Lawrence, B. S. (1989). Organizational demography: The differential effects of age and tenure distributions on technical communication. Academy of Management Journal, 32(2), 353-376. http://dx.doi.org/10.2307/256366 